\title{
Apontamentos sobre a jurisprudência do STJ e do STF em matéria de procedimentos transnacionais de cooperação jurídica.
}

\begin{abstract}
Bruno Rodrigues de Almeida. ${ }^{1}$
Resumo: Uma pesquisa recente na jurisprudência do STJ em matéria de Habeas Corpus revela que o remédio constitucional tem sido utilizado como forma de impedir o andamento das medidas de cooperação judiciária internacional. Com a Emenda Constitucional 45/2004, o STJ passou a ser o Tribunal competente para cuidar dessa matéria, mas algumas decisões do Supremo parecem dar a entender que ainda há possibilidade da Suprema Corte atuar de maneira determinante na jurisprudência do STJ no sistema de cooperação internacional, inclusive para rever decisões daquele Tribunal no tocante às medidas de investigação das atividades criminais transnacionais. Cabe analisar o teor dessas decisões a fim de interpretar garantir a independência e autonomia do Superior Tribunal de Justiça como órgão responsável pelo juízo de delibação das cartas rogatórias passivas e da decisão sobre a concessão do auxílio direto.
\end{abstract}

Palavras-chave: Direito Internacional Privado - Cooperação Internacional - cartas rogatórias - Habeas Corpus auxílio direto - exequatur.

Abstract : A research in the current jurisprudence of Supremo Tribunal Federal reveals that the heroic remedy of Habeas Corpus has been used to stay proceedings of international judicial cooperation Although the $45^{\text {th }}$ Constitutional Amendment has transferred the competence to grant exequatur to the letters rogatory (sent by foreign authorities to Brazil) from STF to Superior Tribunal de Justiça, some recent decisions of our Supreme Court may lead to the conclusion that STF is still entitled to a relevant discretionary power about international cooperation, especially in the field of investigation of transnational criminal activities. It is necessary to analyze such decisions and confront them with the lessons of the Private International Law doctrine in order to keep STJ's independency and autonomy to function as the competent body in granting exequatur to letters rogatory.

Keywords: Private International Law - International Judicial Cooperation - letters rogatory - direct assistance exequatur.

Introdução. ${ }^{2}$

Uma rápida pesquisa na jurisprudência recente do Supremo Tribunal Federal em matéria de Habeas Corpus ${ }^{3}$ revela que são freqüentemente suscitadas questões atinentes à exigência constitucional da prévia concessão exequatur pelo STJ, sendo requerido o remédio heróico para obstar a realização de diligências no território nacional por via do auxílio direto

\footnotetext{
${ }^{1}$ Doutorando em Direito Internacional pela Universidade do Estado do Rio de Janeiro, Mestre em Direito Internacional e Integração Econômica pela Universidade do Estado do Rio de Janeiro, Professor de Direito Internacional, Advogado.

${ }^{2} \mathrm{O}$ presente trabalho constitui atualização de um trecho da pesquisa desenvolvida pelo autor em ALMEIDA, Bruno Rodrigues de. Cooperação Jurídica Internacional em perspectiva: análise da jurisprudência dos Tribunais Superiores brasileiros sobre a denegação do exequatur às cartas rogatórias passivas por ofensa à ordem pública, soberania nacional e os bons costumes. Dissertação de Mestrado em Direito Internacional e Integração Econômica pela Universidade do Estado do Rio de Janeiro. Orientadora: Professora Carmen Tiburcio. Rio de Janeiro: UERJ, 2008.

${ }^{3}$ À guisa de exemplo, veja-se: STF, HC 85.588-1, Relator: Min. Marco Aurélio de Mello, publicado no DJU de 15/12/2006; STF, HC 90.485-1, Relator: Min. Cezar Peluso, publicado no DJU de 08/06/2007; STF, HC 87.7591, Relator: Min. Marco Aurélio de Mello, publicado no DJU de 18/04/2008 e STF, EDCL no HC 91.002-5, Relator: Min. Marco Aurélio de Mello, publicado no DJU de 21/05/2009.
} 
solicitado por autoridades estrangeiras. Já no âmbito do Superior Tribunal de Justiça ${ }^{4}$, foram oferecidas Reclamações ao argumento de que a realização do expediente do auxílio direto representa supressão indevida da competência constitucional deste tribunal para concessão do exequatur às cartas rogatórias passivas.

Mais do que nunca, estes tribunais se deparam com questões processuais tipicamente transnacionais, situação esta que foi propiciada pela conjugação de fatores internos e internacionais.

Dentre os fatores internos, destacam-se a promulgação da Emenda Constitucional $\mathrm{n}^{\mathrm{o}}$ $45^{5}$ que introduziu a alínea " $i$ " do artigo 105, inciso I da Constituição Federal e transferiu para o STJ a competência originária para a concessão de exequatur às cartas rogatórias passivas; e a subseqüente adoção da Resolução $\mathrm{n}^{\circ} 9$ do $\mathrm{STJ}{ }^{6}$ que passou a regulamentar os procedimentos relativos à cooperação jurídica internacional no âmbito daquela corte.

Já pela perspectiva internacional, dê-se destaque para a promulgação de diversos tratados internacionais celebrados pela República Federativa do Brasil sobre a cooperação jurídica internacional, mediante os quais o Estado partilha da preocupação com a escalada da criminalidade transnacional e reconhece que a cooperação interjurisdicional é forma de realização de justiça diligente e eficaz, comprometendo-se a honrar com as obrigações internacionais assumidas por meio daqueles diplomas.

Cumpre analisar essa desejada e salutar complementaridade das conjecturas acima descritas, apreciando a convergência entre os clássicos ramos do Direito Internacional Público e do Direito Internacional Privado, bem como proceder à análise crítica da jurisprudência do STJ e do STF sobre alguns procedimentos de cooperação interjurisdicional.

Discorrer sobre o tema dos procedimentos jurisdicionais que transbordam as fronteiras dos Estados em que são originalmente deflagrados constitui um dos grandes assuntos afetos à disciplina do Direito Internacional Privado, o conflito de jurisdições ${ }^{7}$.

A jurisdição, conforme já explicou Joseph Story ${ }^{8}$, é o poder que um Estado exerce de maneira exclusiva ${ }^{9}$ sobre todas as pessoas e as coisas que se encontram dentro do seu

\footnotetext{
${ }^{4}$ STJ, Reclamação $\mathrm{n}^{\circ}$ 1.819/RJ, Relator: Min. Sálvio de Figueiredo Teixeira, publicado no DJU de 03/03/2005; STJ, Reclamação n ${ }^{\circ}$ 2.645/SP, Relator: Min. Teori Zavascki, publicado no DJU de 23/11/2007.

${ }_{6}^{5}$ Publicada no DJU de 30/12/2004.

${ }^{6}$ Publicada no DJU de 06/05/2005.

${ }^{7}$ DOLINGER, Jacob. Direito Internacional Privado - Parte Geral. $9^{\mathrm{a}}$ edição. Rio de Janeiro: Renovar, 2008, p. $1-5$.

${ }^{8}$ STORY, Joseph. Comentarios sobre el Conflicto de Las Leyes. Claudomiro Quiroga (Trad.). Buenos Aires: Felix Lajouane, 1891, p. 25. Ver também MARCATO, Antonio Carlos. Considerações sobre Jurisdição e Competência. REVISTA IOB de Direito Civil e Processual Civil, $\mathrm{n}^{\circ}$ 46, p.51-74. São Paulo: Thompson, marçoabril, 2007.
} 
território. Dessa forma, as sentenças e demais atos jurisdicionais de um dado Estado estão circunscritos aos limites geográficos do seu território nacional. Estes atos perderão a força mandamental caso ultrapassem as fronteiras da jurisdição doméstica do país de origem, vem daí a necessidade pela cooperação jurídica internacional a fim de efetivar a prestação jurisdicional quando os elementos desta transbordam os limites geográficos da jurisdição doméstica do Estado em que esta ocorre.

Carmen Tiburcio ensina que "do ponto de vista jurídico, o mundo é fracionado em jurisdições, alinhadas, via de regra, às lindes de divisão geopolítica vigentes. Como as decisões e ordens expedidas pela autoridade judiciária de cada Estado têm eficácia somente naqueles limites territoriais de jurisdição, freqüentemente surge a necessidade de estabelecer uma cooperação judiciária internacional." ${ }^{10}$

Assim, a Cooperação Jurídica Internacional é ramo do Direito Processual Internacional que "compreende na verdade o procedimento através do qual é promovida a integração jurisdicional entre Estados soberanos distintos ". ${ }^{11}$

Tal modalidade de cooperação internacional pode ser ativa ou passiva, de acordo com o enfoque que se deseja enfatizar. Portanto, as medidas que um determinado Estado solicita aos demais representam a cooperação ativa, ao mesmo tempo em que a cooperação passiva se realiza através do "intercâmbio internacional para o cumprimento extraterritorial de medidas processuais provenientes do Judiciário de outro Estado" ${ }^{12}$.

Tradicionalmente, a cooperação jurídica internacional se realiza através de cartas rogatórias e do reconhecimento e execução de sentenças estrangeiras, institutos estes consagrados no direito processual brasileiro e de outros países. Em matéria penal, além das modalidades supramencionadas existe ainda a análise do pedido de Extradição e a transferência de presos como formas de cooperação jurídica internacional.

\footnotetext{
9 "Revela-se lesiva à soberania brasileira, e transgride o texto da Lei Fundamental da República, qualquer autorização, que, solicitada mediante comissão rogatória emanada de órgão judiciário de outro País, tenha por finalidade permitir, em território nacional, a inquirição, por magistrados estrangeiros, de testemunha aqui domiciliada, especialmente se pretender que esse depoimento testemunhal - que deve ser prestado perante magistrado federal brasileiro (CF, art. 109, X) - seja realizado em Missão Diplomática mantida pelo Estado rogante junto ao Governo do Brasil." STF, CR n 8.577, Relator: Min. Celso de Mello, publicada no DJU de 01/03/1999.

${ }^{10}$ TIBURCIO, Carmen. Temas de Direito Internacional. Rio de Janeiro: Renovar, 2006, p. 159.

${ }^{11}$ SILVA, Ricardo Perlingeiro Mendes. Cooperação jurídica internacional e auxílio direto In: BARROSO, Luís Roberto e TIBURCIO, Carmen (organizadores). O Direito Internacional Contemporâneo - Estudos em homenagem ao professor Jacob Dolinger. Rio de Janeiro: Renovar, 2006, p.798-800.

${ }^{12}$ ALEMIDA, Ricardo ARAÚJO, Nádia, SALLES, Carlos Alberto. Cooperação Interjurisdicional no Mercosul. Cartas Rogatórias, Homologação de Sentenças Estrangeiras e Laudos Arbitrais e Informação do Direito Estrangeiro. In: BASSO Maristela (org.) Mercosul, seus efeitos jurídicos, econômicos e políticos nos Estados Membros. Porto Alegre: Livraria do Advogado 1997, p. 494. ARAUJO, Nadia de. Direito Internacional Privado - Teoria e Prática Brasileira. $4^{\mathrm{a}}$ edição. Rio de Janeiro: Renovar, 2008, p. 278, especialmente nota 545.
} 
Costuma-se classificar o Sistema de Cooperação Jurídica Internacional em difuso ou concentrado. No primeiro caso $^{13}$, as autoridades judiciárias da primeira instância têm competência tanto para julgar o cabimento, como para conduzir a efetiva realização do pedido de cooperação enviado pelo Estado estrangeiro, enquanto que no sistema concentrado o juízo acerca do cabimento da cooperação é feito por um único órgão (geralmente o órgão de cúpula do Poder Judiciário); tendo sido deferida a solicitação deprecada, a realização desta se dará sob os auspícios de outra autoridade judiciária.

No Brasil, desde a Independência, o sistema de cooperação internacional adotado durante a maior parte do tempo foi, sem dúvida, o sistema concentrado ${ }^{14}$, o qual fora inaugurado ainda no século XIX, mas só veio alcançar status constitucional na Carta de 1934 através dos artigos 76, I, $g$ e 77 que introduziram a homologação de sentenças estrangeiras e a concessão de exequatur às cartas rogatórias no rol das atribuições originárias do STF, situação que permaneceu durante as Constituições que lhe sobrevieram até o advento da Emenda Constitucional $n^{\circ} 45 / 2004$, que reformou a Carta de 1988, deslocando tal competência para o Superior Tribunal de Justiça (CF, art. 105, I, $i$ ). Note-se, entretanto, que o Supremo Tribunal Federal continua competente para a apreciação dos requerimentos de extradição (CF, art. 102, I, g), havendo assim uma bipartição da competência constitucional para processar o juízo de admissibilidade das modalidades clássicas de cooperação interjurisdicional.

No entanto, analisando os mesmos fatores que sustentam o princípio da cooperação internacional, observa-se um interessante fenômeno, através do qual há verdadeira convergência entre o Direito Internacional Público e do Direito Internacional Privado.

Nesse aspecto, Philip Jessup foi um dos primeiros autores a sustentar que devido à crescente complexidade das relações jurídicas no cenário mundial, era preciso superar o hiato hermenêutico e epistemológico estabelecido entre os ramos do Direito Internacional, utilizando então a expressão Direito Transnacional "para incluir todas as normas que regulam atos ou fatos que transcendem as fronteiras nacionais. Tanto o direito público quanto o direito privado estão compreendidos, como estão outras normas que não se enquadram nessas categorias clássicas. " 15.

\footnotetext{
13 "Interessante observar que, na maioria dos países desenvolvidos, a competência para homologar as sentenças estrangeiras é atribuída aos juízes de $1^{a}$ instância (Alemanha, França, Canadá, Suíça, Itália, dentre outros).” Cf. TIBURCIO, Carmen. Temas de Direito Internacional. Rio de Janeiro: Renovar, 2006, p. 195.

${ }_{15}^{14}$ TIBURCIO, Carmen. Temas de Direito Internacional. Rio de Janeiro: Renovar, p. 149-151.

15 JESSUP, Philip. Direito Transnacional. Trad. Carlos Ramires Pinheiro da Silva. Rio de Janeiro: Fundo de Cultura, 1965, p. 12.
} 
O ponto fulcral dessa argumentação lança suas bases na teoria de Hugo Grotius, ao estabelecer que todas as normas de direito são obras típicas da própria atividade humana, e como tal, só existem em função e ao exercício dos interesses do ser humano. Portanto, a bidimensionalidade clássica que contrapõe os ramos do Direito Internacional Público (enquanto conjunto de regras que regula as relações entre os Estados soberanos) e o Direito Internacional Privado (para tratar das questões dotadas do elemento de intersistematicidade) não é suficiente para compreender a conjuntura das situações cotidianas; o que este autor propõe é justamente a complementaridade ao invés da exclusividade ${ }^{16}$.

Conclusão semelhante foi a de Andreas Lowenfeld ${ }^{17}$ durante curso proferido na Academia de Haia, onde, consternado com a tradição bidimensionalista do ensino do Direito Internacional, defendeu que a convergência não mais se baseava em projeções doutrinárias, pois do seu ponto de vista já era realidade palpável:

\begin{abstract}
My thesis is that public international law has been too rigid, too rule-orientated, and therefore too abstract, in part because it has been insulated from the more flexible, approach-oriented developments of private international law. On the other hand, while modern private international law (or conflict of laws), has applied increased sophistication to the solution of wholly private disputes, it has shied away behind ancient slogans reflecting a hostility to or fear of governmental action that seems quite out of place in the second half of the twentieth century.
\end{abstract}

A doutrina nacional contemporânea também partilha dessa idéia como se pode comprovar no entendimento de Cláudia Lima Marques ${ }^{18}$ para quem o Direito Internacional Privado "em plena pós-modernidade, é um ramo misto do Direito, tendo em vista a sua atual pluralidade de métodos, de normas de DIPriv. e o fim das barreiras claras entre os ramos do Direito Privado e do Direito Público.

Marilda Rosado ${ }^{19}$ entende que, diante da complexidade dos novos paradigmas do Direito do Comércio Internacional Contemporâneo, deva-se adotar "uma posição conciliatória, como a de Celso Mello, a propósito da especificidade do Direito Internacional

\footnotetext{
${ }^{16}$ JESSUP, Philip. Direito Transnacional. Trad. Carlos Ramires Pinheiro da Silva. Rio de Janeiro: Fundo de Cultura, 1965, p. 16-20.

${ }^{17}$ LOWENFELD, Andreas F. Public Law in the International Arena: Conflict of Laws, International Law, and some suggestions for their interaction. Haia: Alphen Van Den Rijn - Sitjtholf M. Noodhroff Editores, 1980, p. 321-322.

${ }^{18}$ MARQUES, Cláudia Lima. Ensaio para uma introdução ao Direito Internacional Privado. In: DIREITO, Carlos Alberto Menezes; PEREIRA, Antonio Celso Alves; TRINDADE, Antonio Augusto Cançado (Organizadores). Novas perspectivas do direito internacional contemporâneo - Estudos em homenagem ao Professor Celso D. de Albuquerque Mello. Rio de Janeiro: Renovar, 2008, p. 347.

19 RIBEIRO, Marilda Rosado de Sá. As empresas transnacionais e os novos paradigmas do comércio internacional. In: DIREITO, Carlos Alberto Menezes; PEREIRA, Antonio Celso Alves; TRINDADE, Antonio Augusto Cançado (Organizadores). Novas perspectivas do direito internacional contemporâneo - Estudos em homenagem ao Professor Celso D. de Albuquerque Mello. Rio de Janeiro: Renovar, 2008, p. 460.
} 
Econômico, alinhando-se à posição de Bernejo, eis que esta disciplina, apesar de ser um ramo do direito internacional público, estaria também ligada ao direito internacional privado e à economia política, a qual requer ainda conhecimentos de comércio internacional."

Ricardo Perlingeiro ${ }^{20}$ salienta a importância da convergência entre os ramos do Direito Internacional para a formação do Direito Processual Transnacional e da correlata cooperação jurídica internacional para a garantia dos direitos adquiridos e o respeito à diversidade:

A tutela judicial transnacional é uma exigência dos tempos atuais, em que constantemente as relações jurídicas, sob diversos aspectos, ultrapassam as fronteiras de um Estado. É inconcebível que direitos adquiridos reconhecidos judicialmente sejam desconsiderados ou sofram restrições apenas por necessitarem de efeitos extraterritoriais. Tal situação gera sensação generalizada de impunidade e de injustiça, no campo do direito público e do direito privado, perante o Estado no qual se reconhece o direito, e também no Estado no qual é negado ou dificultado o reconhecimento.

Finalmente, Jacob Dolinger ${ }^{21}$ afirma que proliferação dos temas abordados pelos tratados internacionais transcende o estreito escopo das relações entre Estados soberanos; a crescente participação dos agentes estatais em âmbitos outrora considerados privados ajuda a vislumbrar essa intrínseca complementaridade entre os ramos do Direito Internacional:

Há, inequivocadamente, afinidade entre as duas disciplinas jurídicas, ambas voltadas para questões que afetam os múltiplos relacionamentos, ambas voltadas para questões que afetam os múltiplos relacionamentos internacionais, uma dedicada às questões políticas, militares e econômicas dos Estados em suas manifestações soberanas, a outra concentrada nos interesses particulares, dos quais os Estados participam cada vez mais intensamente. Entre as duas disciplinas tem havido recíproca colaboração por juristas de todo o mundo, para ambas têm sido elaborados tratados e convenções por organismos regionais, e os "princípios gerais de direito reconhecido pelas nações civilizadas” - noção assentada no Regulamento da Corte Internacional de Justiça - norteiam e limitam o legislador e o aplicador da lei em questões que dizem respeito tanto ao Direito Internacional Público como ao Privado.

Portanto, a convergência entre o Direito Internacional Público e o Direito Internacional Privado está fortemente ligada à questão dos tratados internacionais, posto se tratar da articulação de vontades políticas entre entidades soberanas e/ou outros membros da ordem internacional para a produção de normas para toda a miríade de situações jurídicas que serão invocadas por inúmeros operadores do direito.

20 SILVA, Ricardo Perlingeiro Mendes da. Princípios fundamentais e regras gerais da cooperação interjurisdicional consagrados na proposta de Código Modelo para a Ibero-América. Revista Forense v. 388, p. 477-478. Rio de Janeiro: Forense, nov/dez 2006.

${ }^{21}$ DOLINGER, Jacob. Direito Internacional Privado - Parte Geral. $9^{a}$ edição. Rio de Janeiro: Renovar, 2008, p. $12-13$. 
Seja por força de um tratado que institua um Direito Uniformizado entre os ratificantes, ou acordo que estabeleça normas de Direito Internacional Privado Uniformizado, ou mesmo na questão das normas referentes às medidas de cooperação internacional jurídica (típicas do conflito de jurisdições) o que se percebe é a aproximação cada vez mais acelerada entre os ramos institucionais do Direito Internacional que devem se complementar na busca pela solução das controvérsias jurídicas.

Criminalidade Transnacional e Cooperação Jurídica Internacional.

O crime organizado é, de fato, tão antigo quanto às sociedades civilizadas, mas a escalada do Crime Organizado Transnacional, (T.O.C em inglês) é considerada um dos subprodutos da globalização, muito embora se possa criticar a "novidade" dessa conjuntura, pois circunstâncias em que a complexidade das práticas criminosas transborda as fronteiras dos Estados podem ser remontadas até pelo menos o início da expansão colonialista européia no início do século XVI ${ }^{22}$.

Não é difícil constatar que os mesmos fatores impulsionadores da globalização econômica serviram também no auxílio à disseminação das atividades criminosas pelo mundo sem fronteiras, retornando à idéia de que a atividade criminosa foi catapultada à escala que propositalmente transborda os limites geográficos e jurídicos no intuito de se evadir da persecução criminal:

\begin{abstract}
O tráfico de entorpecentes passou a se estruturar em redes internacionais; o lenocínio passou a tirar proveito das diferenças de preços nos mercados de prostituição e formou densos fluxos de tráfico de exercentes da atividade; o enrijecimento dos controles imigratórios nos países desenvolvidos fez surgir o tráfico de trabalhadores, que conferiu, por sua vez, nova dimensão aos crimes de falsidade moral e ideológica e de corrupção; o contrabando e o descaminho se profissionalizaram e passaram a se articular com a indústria da contrafação, em autênticas redes de fornecimento e distribuição (e.g. bebidas alcoólicas, produtos de tabaco, programas de computador, fonogramas); o tráfico de armas deixou de processar-se à sombra estatal e passou a municiar organizações criminosas ou terroristas, que cada vez mais passaram a contar com autênticas forças privadas de segurança; a lavagem de ativos floresceu no bojo dos meios técnicos e dos arranjos institucionais de aproximação dos sistemas financeiros nacionais; a Internet tornouse plataforma para novos e estruturados modos de execução de tipos penais já existentes, como o furto, o estelionato, a extorsão, os crimes contra a honra e contra os bons costumes. ${ }^{23}$
\end{abstract}

\footnotetext{
${ }^{22}$ VAN DUYNE, P.C. The Phantom and Threat of Organized Crime .In: Crime, Law and Social Change, vol. 24. Nova York: Springer, 1995, p. 341-377.

${ }^{23}$ MILLER, Marcello Paranhos de Oliveira. $O$ auxílio direto em matéria penal: a moldura jurídica de uma nova vertente da cooperação internacional. Dissertação de Mestrado em Direito Internacional e Integração Econômica pela Universidade do Estado do Rio de Janeiro. Orientadora: Professora Carmen Tiburcio. Rio de Janeiro: UERJ, 2008, p. 21.
} 
Dessa forma, a primeira dificuldade encontrada pelos Estados no combate ao crime organizado transnacional reside justamente na formação de um conceito jurídico capaz de se adaptar à sua complexa estrutura, pois se os princípios do Direito Penal são fortemente atrelados ao conceito de soberania estatal, uma visão retrógrada e desinteressada na conjuntura mundial desse atributo certamente se refletirá na efetividade dos resultados obtidos no combate dessas atividades.

Há três principais correntes na conceituação de Crime Organizado Transnacional: uma centrada na natureza ilícita de determinadas atividades econômicas que transbordam as fronteiras do Estado; uma segunda focada na qualidade do grupo ou entidade e uma terceira, que é calcada nos efeitos transnacionais do crime organizado ${ }^{24}$. Como estas conceituações não são contraditórias e sim complementares, a Convenção da ONU contra o Crime Organizado Transnacional ${ }^{25}$ trabalha com as três teorias tentando refletir o maior espectro possível para a idéia de transnacionalidade.

Entretanto, é importante atentar para o alerta do Instituto Internacional da Paz, pois mesmo os diplomas como a Convenção de Palermo conceituam o Crime Organizado Transnacional com base em prévias experiências dos Estados, ou seja, é a formação de um conceito baseado no passado para algo que se projeta necessariamente para o futuro, o que dificulta a compreensão de sua evolução, na medida em que a atividade criminosa está sempre se modificando com vistas a se evadir da norma jurídica incriminadora.

No ano de 2005, o tráfico de entorpecentes foi estimado em 322 bilhões de dólares norte-americanos, o que em termos de produto interno bruto equivaleria à trigésima posição mundial; somente o tráfico de seres humanos representa um negócio que movimenta cerca de dez bilhões de dólares norte-americanos por ano. No mesmo período o comércio internacional de produtos contrafeitos foi estimado entre quatrocentos e seiscentos milhões de dólares norte-americanos, demonstrando um crescimento até oito vezes superior ao volume do comércio internacional regular de produtos no período entre 1990 e $2005^{26}$.

Apesar da impactante constatação desses números há que se refletir sobre outro grande obstáculo no combate à criminalidade transnacional que consiste na dificuldade na quantificação dessas atividades, o que só disfarça a verdadeira pujança desse problema,

${ }^{24}$ COCKAYNE, James. Transnational Organized Crime: multilateral responses to a rising threat. 2007. Disponível em http://www.ipacademy.org/asset/file/159/CWC_Working _Paper_ORGANIZED_CRIME_JC.pdf. Acesso em 03/08/2009.

${ }^{25}$ Promulgada pelo Decreto $\mathrm{n}^{\circ} 5.015$ de 12/03/2004.

${ }^{26}$ COCKAYNE, James. Transnational Organized Crime: multilateral responses to a rising threat. 2007. Disponível em http://www.ipacademy.org/asset/file/159/CWC_Working _Paper_ORGANIZED_CRIME_JC.pdf. Acesso em 03/08/2009. 
especialmente quando provocada em função da inércia ou coação das vítimas ou ainda pela atuação de agentes governamentais corruptos:

Weak governance allows TOC to forge a symbiosis with politics, hindering development and reducing the capacity of states to manage social tension and conflict. As a result, the convergence of TOC, state failure, and armed conflict poses an increasingly obvious threat to global security. Drug-trafficking networks spread violence, corruption, conflict, and disease from Latin America and Afghanistan, through West Africa, to North America and Europe. Pirates threaten global trade through the Straits of Molucca and the Gulf of Aden. Global arms traffickers, such as the recently apprehended Viktor Bout, fuel wars throughout Africa, Asia, and the Middle East, avoiding United Nations arms embargoes and trading arms for diamonds, timber, coltan, cars-and even humans. European and other criminal gangs plunder the maritime resources of the coasts of Africa, and dump toxic waste into waters unpoliced by coastguards. And criminal networks facilitate the proliferation of nuclear materiel and expertise, risking their passage into the hands of terrorists. ${ }^{27}$.

Diante de tão graves riscos, a importância da cooperação internacional jurídica fundamenta-se na própria necessidade de preservação da Sociedade Internacional contemporânea, pois há ainda o grande perigo de que certas ameaças à segurança transnacional tais como o crime organizado transnacional e as redes terroristas estejam, conforme apontam certos estudos ${ }^{28}$, numa tendência convergente, o que efetivamente deve ser levado em conta na conduta das autoridades dos diversos Estados para facilitar a cooperação internacional jurídica em todas as suas formas e possibilidades, pois conforme explica Wagner Menezes ${ }^{29}$ :

Essa relação transnormativa se caracteriza por vários fatores de alocação de uma realidade internacional que, através de seus instrumentos normativos produzidos no plano internacional, dissolvem as fronteiras e possibilitam uma interpretação de normas jurídicas entre o local e o global em um mesmo espaço de soberania e competência normativa. Elementos de fundamentação da construção normativa, como as fontes de direito, incluindo as soft law; o direito comunitário e seus mecanismos específicos de regulamentação intrabloco; as regras de direitos humanos que passam de uma simples resolução e adotam cada vez mais o caráter de um ius cogens um direito imperativo que deve ser respeitado e observado por todos os povos.

\footnotetext{
${ }^{27}$ Conferir IBI Blue Papers \#2 Transnational Organized Crime - Task Forces in Strengthening Multilateral Security Capacity, 2009. Disponível em http://www.ipacademy.org/asset/file/426/TOC_FINAL.pdf. Último acesso em 03/08/2009.

${ }^{28}$ COCKAYNE, John; MIKULASCHEK, Cristoph. Transnational Security Challenges and the United Nations: Overcoming Sovereignty Walls and Institutional Silos, 2008. Disponível em http://www.ipacademy.org/asset/file/253/westpoint.pdf. Último acesso em 03/08/2009.

${ }^{29}$ MENEZES, Wagner. O direito internacional e a teoria da transnormatividade. In: DIREITO, Carlos Alberto Menezes; PEREIRA, Antonio Celso Alves; TRINDADE, Antonio Augusto Cançado (Organizadores). Novas perspectivas do direito internacional contemporâneo - Estudos em homenagem ao Professor Celso D. de Albuquerque Mello. Rio de Janeiro: Renovar, 2008, p. 990.
} 
Além da Convenção de Palermo sobre Crime Organizado Transnacional, o Brasil também ratificou outros instrumentos multilaterais muito importantes em matéria de cooperação internacional voltados para o combate à criminalidade organizada transnacional, tais como a Convenção das Nações Unidas sobre o Tráfico Ilícito de Narcóticos e Substâncias Psicotrópicas; Convenção das Nações Unidas contra a Corrupção ${ }^{30}$; a Convenção Interamericana sobre Auxílio Mútuo em Matéria Penal, ${ }^{31}$ e o Protocolo de Assistência Jurídica Mútua em Assuntos Penais do Mercosul ${ }^{32}$.

Vê-se, portanto, que o Estado brasileiro partilha da preocupação com a escalada do crime organizado transnacional e, por meio de diversos diplomas assumiu compromissos internacionais de auxílio e cooperação, motivo pelo qual a atividade jurisdicional em tais casos deve atuar de maneira consciente e sensível à transnacionalidade das questões processuais ${ }^{33}$.

O impacto das transformações no Direito Internacional Contemporâneo sobre o Sistema de Cooperação Jurídica Internacional aplicado no ordenamento brasileiro.

Apesar da importância constitucional que a cooperação internacional possui para o ordenamento jurídico nacional, a sua regulamentação atual é bastante fragmentada, pois não há uma lei específica cuidando de toda a matéria, que está presente, de forma esparsa, em diversos diplomas jurídicos, além da própria Constituição Federal, como nas regras da Lei de Introdução ao Código Civil, no Código de Processo Civil, no Código de Processo Penal, no Regimento Interno do STF e com o advento da EC no 45/2004, a partir de 4/05/2005, a Resolução $n^{\circ}$ 9/2005 do Superior Tribunal de Justiça passou a ser o regulamento geral aplicável aos procedimentos referentes à concessão de exequatur às cartas rogatórias passivas bem como a ação de homologação de sentenças estrangeiras e as modalidades do auxílio direto.

De lege ferenda, dê-se destaque para alguns esforços no sentido da harmonização do tratamento destinado à cooperação jurídica internacional no ordenamento brasileiro. Um deles

\footnotetext{
${ }^{30}$ Promulgada pelo Decreto $\mathrm{n}^{\mathrm{o}} 5.687$ de $31 / 01 / 2006$.

${ }^{31}$ Promulgada pelo Decreto $\mathrm{n}^{\mathrm{o}} 6.340$ de $3 / 01 / 2008$.

${ }^{32}$ Promulgado pelo Decreto no 3.468 de 17/05/2000.

33 O Ministério da Justiça está liderando essa transformação, com a elaboração de uma Lei de Cooperação Jurídica Internacional. Também criou o Departamento de Recuperação de Ativos e Cooperação Jurídica Internacional (DRCI) no âmbito da Secretaria Nacional de Justiça do Ministério da Justiça (www.mj.gov.br/drci).
} 
é o Anteprojeto de Lei de Cooperação Jurídica Internacional ${ }^{34}$, cuja Comissão de Elaboração foi instituída pela Portaria do Ministério da Justiça $n^{\circ}$ 2.199/2004 e que elenca seis espécies de modalidades de cooperação jurídica internacional no seu art. $1^{\circ}$ (homologação de sentenças estrangeiras, concessão de exequatur às cartas rogatórias, auxílio direto, transferência de processos penais, extradição e transferência de pessoas apenadas).

Já no âmbito da região ibero-americana existe o Código Modelo de Cooperação Interjurisdicional para a Íbero-América (cuja Comissão Revisora foi presidida por Ada Pellegrini Grinover e secretariada por Ricardo Perlingeiro) que foi aprovado pela Assembléia Geral do Instituto Ibero-Americano de Direito Processual em 17 de outubro de 2008, este Código não consiste em um projeto de tratado a ser ratificado pelos países da região, mas sim "uma proposta de normas nacionais a serem incorporadas internamente por países iberoamericanos e destinada a cooperação com qualquer Estado, ibero-americano ou não", 35

Deve-se compreender que o contexto dessas evoluções foi, na verdade, uma transposição das inovações referentes à cooperação internacional jurídica no mundo inteiro, pois é impossível dissociar o influxo das transformações verificadas no cenário mundial sobre a própria realidade nacional, nesse sentido dê-se destaque para o professado de Nadia de Araujo ${ }^{36}$ :

\begin{abstract}
Para garantir a rapidez e a eficácia do trânsito de atos processuais e jurisdicionais são necessárias normas especiais, que permitam o cumprimento dessas medidas. Essa obrigação dos Estados resulta de um dever de cooperação mútua para assegurar o pleno funcionamento da Justiça. Ao mesmo tempo, deve-se também assegurar os direitos fundamentais protegidos no âmbito da Constituição e dos Tratados internacionais de direitos humanos. Esses direitos fazem parte de um catálogo de direitos do cidadão e não mais de uma obrigação entre nações soberanas, por força da cortesia internacional. Vislumbra-se uma relação direita entre esses atos processuais transfronteiriços e os direitos fundamentais através do processo no qual as garantias de defesa sejam respeitadas. Há uma preocupação do esforço codificador internacional em encontrar soluções uniformes, no plano global, por meio de convenções internacionais, multilaterais ou oriundas de processos de integração.
\end{abstract}

Assim, no plano do Direito da Integração Econômica, os Estados celebraram diversos acordos multilaterais visando alcançar mecanismos mais céleres para a realização da

\footnotetext{
${ }^{34}$ Para análise dos dispositivos referentes às modalidades de cooperação em matéria penal veja-se MILLER, Marcello Paranhos de Oliveira. O auxílio direto em matéria penal: a moldura jurídica de uma nova vertente da cooperação internacional. Dissertação de Mestrado em Direito Internacional e Integração Econômica pela Universidade do Estado do Rio de Janeiro. Orientadora: Professora Carmen Tiburcio. Rio de Janeiro: UERJ, 2008, p. 157-166.

${ }^{35}$ Cf. Código Modelo de Cooperacíon Interjurisdiccional para Iberoamerica. Revista de Processo $\mathrm{n}^{\circ}$ 166, p. $203-$ 229. São Paulo: RT, dezembro 2008.

${ }^{36}$ ARAUJO, Nadia de. Direito Internacional Privado - Teoria e Prática Brasileira. $4^{a}$ edição. Rio de Janeiro: Renovar, 2008, p. 279-280.
} 
cooperação jurídica, o que na verdade representa uma das vertentes dos diferentes projetos de integração econômica, cuja expressão máxima de desenvolvimento se verifica no estabelecimento de uma regra supranacional referente aos procedimentos de jurisdição transnacional intra-bloco, conforme dispõe o Regulamento n ${ }^{\circ} 44$ da União Européia ${ }^{37}$.

Em outros casos tais como a Convenção da ONU sobre a Prestação de Alimentos no Estrangeiro ${ }^{38}$ fica estabelecido, dentre outras provisões, um sistema de auxílio direto através da articulação entre autoridades intermediárias nos países ratificantes do acordo para resolver questões de representatividade processual que tornavam quase impossível o acesso aos tribunais estrangeiros. Vale lembrar ainda das inovações trazidas pela Convenção da Haia sobre os Aspectos Civis do Seqüestro Internacional de Crianças ${ }^{39}$ pela qual a Autoridade Central nacional vai atuar perante o Judiciário local no intuito de retornar o menor à sua residência habitual o mais rápido possível.

Há também a questão dos tratados bilaterais de cooperação judiciária ratificados pela República Federativa do Brasil ${ }^{40}$, pois, conforme já mencionado anteriormente, estes são verdadeiramente "tratados contrato", devido ao caráter da especialidade de suas regras, que cuidam especificamente da cooperação jurídica internacional exclusivamente entre as partes ratificantes.

Dessa forma, as modalidades clássicas de cooperação vêm sendo reformuladas na medida em que implicam, muitas vezes, em expedientes morosos e burocráticos, abrindo espaço para o surgimento de uma nova espécie de cooperação internacional, o chamado auxílio direto ou assistência direta, conforme explica Maria Rosa Loula ${ }^{41}$ :

\begin{abstract}
A "assistência direta" é um novo mecanismo de cooperação jurídica internacional que não se confunde com a carta rogatória e nem com a homologação de sentença estrangeira. Trata-se de um procedimento inteiramente nacional, que começa com uma solicitação de ente estrangeiro para que um juiz nacional conheça de seu pedido como se o procedimento fosse interno. Ou seja, a autoridade ou parte estrangeira fornece os elementos de prova para a autoridade central que encaminha o caso para o MPF (penal) ou AGU (civil) propor a demanda desde o início. Por isso a assistência direta difere da carta rogatória. Na carta rogatória passiva há uma ação no estrangeiro e o juiz estrangeiro solicita que juiz nacional pratique certo ato (e já diz qual é o ato). O juiz nacional só pode praticar aquele ato ou negar aplicação (no
\end{abstract}

\footnotetext{
37 Sobre a questão veja-se, dentre outros, SALDANHA, Jânia Maria Lopes; LISBOA, Ramon. Justiça transfronteiriça: uma análise comparativa das estruturas judiciais e mecanismos de cooperação jurisdicional de cooperação em matéria civil e comercial entre Mercosul e União Européia. Revista de Processo $\mathrm{n}^{\circ}$ 157, p. 145163. São Paulo: RT, outubro, 2007.

${ }^{38}$ Promulgada no Brasil pelo Decreto no 58.826 de 02/09/1965.

${ }^{39}$ Promulgada no Brasil pelo Decreto no 3.413 de 14/04/2000.

${ }^{40}$ Para a lista dos acordos internacionais bilaterais, tanto na área cível, quanto penal, já ratificados pelo Brasil, confira-se o site do Ministério da Justiça, em www.mj.gov.br/drci.

${ }^{41}$ LOULA, Maria Rosa Guimarães apud ARAUJO, Nadia de. Direito Internacional Privado - Teoria e Prática Brasileira. $4^{\circ}$ edição. Rio de Janeiro: Renovar, 2008, p. 282, nota 554.
} 
caso de ofensa à ordem pública). A assistência direta começou nos países de Common Law e nestes ele não difere muito da carta rogatória. Este procedimento começou a ser utilizado no Brasil para resolver o impasse criado pela jurisprudência do STF sobre cartas rogatórias executórias. Este procedimento está bem descrito no acordo bilateral Br-EUA e no Protocolo de São Luís, Mercosul (assistência judicial em matéria penal)

Diante dessa pluralidade de normas e tratamentos diversos referentes à matéria, destacam-se as seguintes situações: (i) as normas vigentes para os países com os quais o Brasil possui regras internacionais já definidas, como, por exemplo, os países membros do Mercosul e as Convenções da ONU em matéria de cooperação; (ii) nos casos de tratado ou convenção de cooperação jurisdicional bilateral aplicável, (por exemplo os tratados com a Espanha ${ }^{42}$ com a França ${ }^{43}$, a Itália ${ }^{44}$ e Portugal $^{45}$ ); (iii) a situação dos países com os quais o Brasil não possui qualquer tratado ou convenção internacional, aplicando-se a esses casos as regras da legislação ordinária, ou eventual compromisso de reciprocidade efetuado.

A Resolução nº 9/ 2005 do STJ foi, sem dúvida, um marco histórico para o sistema brasileiro de cooperação jurídica internacional, especialmente ao tentar adotar medidas desburocratizantes e que conferem agilidade aos procedimentos, tais como a possibilidade de concessão da tutela de urgência na ação de homologação de sentença estrangeira ( $\operatorname{art.} 4^{\circ} \S 3^{\circ}$ ), a possibilidade para realização de cartas rogatórias "de cunho decisório" tais como a quebra de sigilo bancário e telefônico (art. $7^{\circ}$, caput); a conversibilidade do expediente da carta rogatória em auxílio direto quando o Presidente do STJ julgar que a diligência requerida não enseja juízo de delibação (art. $7^{\circ}, \S$ único) e a possibilidade da concessão de exequatur às cartas rogatórias sem prévia intimação do interessado quando isto implicar na própria ineficácia da medida (art. $8^{\circ} \S$ único).

Em ambos os casos, entretanto, o que se pretende é viabilizar uma prestação jurisdicional que se desenvolve perante a autoridade de outro Estado, daí porque, para fins da cooperação internacional em sentido estrito, o emprego da carta rogatória ou do auxílio direto não possui diferenças acentuadas quanto aos resultados obtidos, conforme se deduz do parágrafo único do art. $7^{\circ}$, Res. 9 que permite a conversibilidade do expediente da Carta

\footnotetext{
${ }^{42}$ Convênio de Cooperação Judiciária em Matéria Civil, promulgado pelo Decreto ${ }^{\circ}{ }^{166}$ de 03/07/1991 e Tratado sobre Transferência de Presos, promulgado pelo Decreto ${ }^{\circ} 2.576$ de 22/04/1998.

${ }^{43}$ Acordo de Cooperação Judiciária em Matéria Penal, promulgado pelo Decreto $n^{\circ} 3.324$ de 30/12/1999 e Acordo de Cooperação Judiciária em Matéria Civil, promulgado pelo Decreto no 3.598 de 12/09/2000.

${ }^{44}$ Tratado Relativo à Cooperação Judiciária e ao Reconhecimento e Execução de Sentenças em Matéria Civil, promulgado pelo Decreto no 1.476 de 02/05/1995; Tratado sobre Cooperação Judiciária em Matéria Penal, promulgado pelo Decreto ${ }^{\circ} 862$ de 09/07/1993.

${ }^{45}$ Tratado de Auxílio Mútuo em Matéria Penal, promulgado pelo Decreto no 1.320 de 30/11/1994; Tratado de Amizade, Cooperação e Consulta; promulgado pelo Decreto no 3.927 de 19/09/2001.
} 
Rogatória em prestação do auxílio direto, quando a medida requerida não ensejar, segundo entendimento do Presidente do STJ, juízo de delibação.

Assim, pode-se afirmar que a jurisprudência dos Tribunais Superiores Brasileiros encontra-se num momento crucial para a Cooperação Judiciária Internacional, especialmente em matéria de cartas rogatórias e do auxílio direto, motivo pelo qual é importante analisar as tendências verificadas na jurisprudência recente.

\section{Cartas Rogatórias, Auxílio Direito e Habeas Corpus.}

Em decorrência da natureza jurisdicional da atividade de cooperação entre os Estados, é conferido aos jurisdicionados a possibilidade de oferecer resistência à pretensão jurídica de produção de efeitos no território nacional de atos e proferidos em foros alienígenas, como corolário às garantias constitucionais do devido processo legal, da ampla defesa e ao contraditório. O sistema de cooperação adotado pela Resolução $\mathrm{n}^{\circ}$ 9, na linha do direito anterior, não admite um novo julgamento de mérito tanto nos casos das medidas deprecadas nas cartas rogatórias bem como em relação às sentenças estrangeiras que se pretenda homologar no país. ${ }^{46}$

Devido a essa restrição na matéria de defesa, durante a praxe do STF, o procedimento relativo às cartas rogatórias e sentenças estrangeiras ficou consagrado como sendo de contenciosidade limitada, enfatizando que no seu juízo de delibação, a autoridade nacional teria o máximo de deferência para com o ato que lhe fora submetido ${ }^{47}$. Portanto, também pelo direito atualmente em vigor, apenas as matérias previstas no artigo $9^{\circ}$ (autenticidade dos documentos, inteligência da decisão e ofensa à soberania nacional e à ordem pública) poderão

\footnotetext{
${ }^{46}$ Veja-se, a este respeito, o professado de BARBOSA MOREIRA, José Carlos. Problemas relativos aos litígios internacionais. In: Temas de Direito Processual - Quinta Série. São Paulo: Saraiva, 1994, p. 154-155.

47 "Carta rogatória passiva. Impugnação. Sistema de contenciosidade limitada. Impossibilidade de discussão do mérito da causa perante o STF. A questão da competência internacional concorrente da justiça brasileira. Efetivação, no Brasil, da citação de pessoa aqui domiciliada. Exequatur concedido. (...) Mérito da causa. Impossibilidade de sua discussão no procedimento rogatório - sistema de contenciosidade limitada. Em tema de comissões rogatórias passivas - tanto quanto em sede de homologação de sentenças estrangeiras -, o ordenamento normativo brasileiro instituiu o sistema de contenciosidade limitada, somente admitindo impugnação contrária à concessão do exequatur, quando fundada em pontos específicos, como a falta de autenticidade dos documentos, a inobservância de formalidades legais ou a ocorrência de desrespeito à ordem pública, aos bons costumes e à soberania nacional. Torna-se inviável, portanto, no âmbito de cartas rogatórias passivas, pretender discutir, perante o Tribunal do foro (o Supremo Tribunal Federal, no caso), o fundo da controvérsia jurídica que originou, no juízo rogante, a instauração do pertinente processo, exceto se essa questão traduzir situação caracterizadora de ofensa à soberania nacional ou de desrespeito à ordem pública brasileira." STF, CR no 8.346, Relator: Min. Celso de Mello, publicada no DJU de 26/04/1999.
} 
ser aventadas pela parte contrária à produção de efeitos no território nacional daquela decisão estrangeira. $^{48}$

Logo após o advento da Resolução $\mathrm{n}^{\circ}$ 9, notou-se o incremento da realização das medidas de cooperação internacional jurídica por parte das autoridades brasileiras, seja pela via da carta rogatória ou até mesmo do auxílio direto, principalmente em matéria da cooperação jurídica internacional referente às diligências investigativas no âmbito de tratados de cooperação jurídica ratificados pela República Federativa do Brasil (tais como a quebra de sigilo bancário, telefônico e fiscal ${ }^{49}$ ), mas ainda não se pode afirmar que a jurisprudência dos Tribunais Superiores brasileiros seja favorável à cooperação jurídica internacional.

As mudanças implementadas pela EC 45/2004 fizeram com que a competência em matéria de cooperação jurídica internacional fosse bipartida entre o STF e o STJ, sendo que o juízo de delibação referente às cartas rogatórias deve ser feito agora perante este último. É preciso lembrar ainda que, em matéria do cumprimento das diligências contidas nas cartas rogatórias que receberam o exequatur do STJ é competente a Justiça Federal (art. 109, X, CF), cabendo embargos diretamente ao Presidente do STJ das decisões do juiz federal durante a realização destes atos (art. 13 , caput $\S 1^{\circ}$ e $2^{\circ}$, Res. $n^{\circ} 9$ ).

Devido a essa peculiar partilha para análise de cabimento e efetivo cumprimento dos procedimentos em matéria de cooperação jurídica internacional, não é de se estranhar a nítida possibilidade da Suprema Corte ser instada a se pronunciar na salvaguarda de matéria constitucional representada na violação de direitos fundamentais possivelmente ocorridos nos procedimentos transnacionais de cooperação jurídica, seja pela via do Recurso Extraordinário ou até mesmo pelo uso do remédio heróico do Habeas Corpus, alerta este que já fora feito por parte da doutrina desde a promulgação da $\mathrm{EC} \mathrm{n}^{\mathrm{o}} 45 / 04^{50}$.

Pode-se vislumbrar essa divergência de entendimentos em alguns exemplos recentes da jurisprudência dos Tribunais Superiores, como no caso do $\mathrm{HC}$ n. ${ }^{\circ} 85.588^{51}$, de relatoria do Ministro Marco Aurélio no qual, por maioria, foi inadmitida a realização da cooperação no Brasil por via diversa da Carta Rogatória:

\footnotetext{
48 “CARTA ROGATÓRIA. AGRAVO REGIMENTAL. OFENSA À ORDEM PÚBLICA E À SOBERANIA NACIONAL. INOCORRÊNCIA. 1. Não cabe examinar, no cumprimento de cartas rogatórias, as questões de fundo envolvidas na ação em trâmite na Justiça rogante. Deve verificar-se apenas se a diligência solicitada ofende a soberania nacional e a ordem pública, bem como se há autenticidade dos documentos e observância dos requisitos previstos na Resolução n. 9/2005, deste Tribunal. 2. Agravo regimental improvido.” STJ, AgRg na CR $\mathrm{n}^{\circ}$ 1.110, Relator: Ministro Barros Monteiro, publicada no DJ de 01/08/2006.

${ }^{49}$ Veja-se a mudança na tendência pela concessão dessas medidas nas seguintes decisões: STJ, CR n 438 , Relator: Ministro Luiz Fux, publicada no DJU de 24/09/2007 e STJ, Edcl CR nº 438, Relator: Min. Luiz Fux, publicada no DJU de 20/10/2008.

${ }^{50}$ TIBURCIO, Carmen. Temas de Direito Internacional. Rio de Janeiro: Renovar, 2006, p. 191.

${ }^{51}$ STF, HC no 85588, Relator: Min. Marco Aurélio, publicado no DJ 15/12/2006
} 
CRIME - COOPERAÇÃO INTERNACIONAL - COMBATE - DILIGÊNCIAS TERRITÓRIO NACIONAL - MEIO. A prática de atos decorrentes de pronunciamento de autoridade judicial estrangeira, em território nacional, objetivando o combate ao crime, pressupõe carta rogatória a ser submetida, sob o ângulo da execução, ao crivo do Superior Tribunal de Justiça, não cabendo potencializar a cooperação internacional a ponto de colocar em segundo plano formalidade essencial à valia dos atos a serem realizados.

Cumpre fazer uma retrospectiva histórica desse caso, pois se refere às investigações referentes a crimes contra a Administração Pública e de lavagem de dinheiro em ação penal desenvolvida no Estado do Rio de Janeiro, onde parte das atividades teria sido realizada por meio da abertura de contas bancárias na Confederação Helvética (Suíça), motivo pelo qual o juízo brasileiro remeteu Carta Rogatória (ativa) no 1/2003 (convertida em solicitação de auxílio direto em matéria penal por sugestão do Ministério da Justiça) para assim requerer às autoridades suíças a remessa de "toda documentação que instrui os procedimentos em curso nesse País concernentes aos fatos relatados no período de colaboração mútua por motivo penal”.

Pouco tempo depois, as autoridades suíças enviaram ao Brasil uma carta rogatória informando intenção de atender à solicitação brasileira requerendo também realização de diligências às autoridades brasileiras (tais como inquirição de testemunhas, cópia de documentos e a participação de autoridades suíças durante a realização dos procedimentos), a fim de manter a simetria na realização do auxílio direto em matéria penal, o Ministério da Justiça remeteu o expediente diretamente ao Tribunal Regional Federal da $2^{\mathrm{a}}$ Região, onde o Relator Ministro André Fontes exarou despacho para realizar as audiências em cumprimento do pedido de cooperação internacional jurídica.

Esta decisão deu causa ao oferecimento da Reclamação $\mathrm{n}^{\circ} 1.819$ por um dos interessados, sob o argumento de alegada usurpação da competência do STJ, na medida em que, segundo o Reclamante, tais diligências antes deveriam receber o exequatur daquele Tribunal conforme consta do art. 105, I, “i”, da Constituição Federal.

O Ministro Relator Sálvio Teixeira suspendeu liminarmente as audiências, decisão esta que foi agravada pelo Ministério Público Federal e posteriormente reformada pela Corte Especial do STJ ${ }^{52}$ num entendimento que, segundo Carmen Tiburcio, ${ }^{53}$ atuou em defesa da necessidade de cooperação internacional:

\footnotetext{
${ }^{52}$ STJ, Reclamação n ${ }^{\circ}$ 1.819, Relator: Min. Sálvio de Figueiredo Teixeira, publicada no DJU de 03/03/2005.

${ }^{53}$ TIBURCIO, Carmen. Uma breve análise sobre a jurisprudência dos Tribunais superiores em matéria de Direito Internacional no ano de 2006. REVISTA DE DIREITO DO ESTADO, Ano 2, $\mathrm{n}^{\circ}$ 5. Rio de Janeiro: Renovar, 2007, p. 78.
} 
A Corte Especial distinguiu dois tipos de pedidos formulados por autoridades estrangeiras: (1) aqueles que visam dar eficácia no Brasil a decisões já tomadas no exterior; e (2) aqueles que solicitam determinada diligência no Brasil, provocando o juiz brasileiro a se manifestar e, fornecendo todos os elementos para sua cognição como em um procedimento doméstico, com o objetivo de ajuizar uma ação ou de instruir um processo judicial já instaurado no exterior.

No primeiro caso, como regra geral, há a necessidade de carta rogatória, pois se pretende conferir eficácia no Brasil a decisões proferidas no exterior. No segundo caso, a autoridade estrangeira solicita que a decisão seja tomada por juiz brasileiro, razão pela qual não haveria necessidade de rogatória, pois o juízo decisório - sobre o cabimento e a procedência ou não do pedido - será feito por autoridade nacional. Nessa linha, decidiu a Corte Especial do Superior Tribunal de Justiça ser válida a cooperação formulada pela via do auxílio direto, ou seja, sem recurso à rogatória.

Em virtude da matéria inerente ao direito fundamental de liberdade, foi impetrado Habeas Corpus n 85.588 perante o STF com fundamento no art. 102, I, “ $i$ ” da Constituição Federal, através do qual a Suprema Corte acabou decidindo em favor do impetrante, por entender que o sistema pátrio de cooperação jurídica internacional consagra a necessidade de pronunciamentos judiciais estrangeiros necessariamente estarem sujeitos à prévia apreciação do STJ:

\begin{abstract}
tais atos hão de ser precedidos de carta rogatória e do correspondente endosso, em termos de execução, pelo Superior Tribunal de Justiça, preservando-se assim, além da triagem imposta constitucionalmente - hoje a cargo dessa Corte Superior de Justiça - , observada a forma essencial à validade do ato, ou seja, à execução da carta rogatória, a soberania nacional
\end{abstract}

Assim, o artigo 105, I, “ $i$ ” seria uma regra constitucional que impediria a "queima de etapas" mediante atuação direta dos órgãos judicantes nacionais, o teor dessa decisão é no sentido de que economia processual não pode sobrepor-se à triagem imposta constitucionalmente, sob pena de ofensa ao devido processo legal e à soberania nacional, tendo sido invalidados todos os atos praticados no âmbito da Justiça Federal através do auxílio direto.

Tal fundamento, entretanto, não está isento de críticas. Primeiro porque há reiteradas manifestações anteriores do próprio STF acerca da possibilidade da realização do auxílio direto lastreado na existência de tratados de auxílio mútuo entre o Brasil e o Estado requerente, como no julgamento das Cartas Rogatórias $n^{\circ} 10.711,10.920$ e $10.922{ }^{54}$. Nos três casos, foi decidido que as Rogatórias não seriam conhecidas, tendo sido determinada a remessa dos autos à Procuradoria-Geral da República, a fim de que providenciasse as medidas

\footnotetext{
${ }^{54}$ STF, CR no 10.711, Relatora: Min. Ellen Gracie, publicada no DJU de 11/09/2003; STF, CR no 10.920, Relator: Min. Ellen Gracie, publicada no DJU de 10/10/2003; STF, CR no 10.922, Relator: Min. Ellen Gracie, publicada no DJU de 12/12/2003.
} 
cabíveis, em cumprimento às regras constantes no Tratado de Auxílio Mútuo em Matéria Penal Brasil-Portugal (Decreto $n^{\circ} 1.320$ de 30/11/2004).

Aliás, antes mesmo da Res. 9 do STJ a existência de tratado internacional sobre cooperação não constituía requisito indispensável para a concessão do auxílio direto, como ficou decidido no julgamento das Cartas Rogatórias $n^{\circ} 10.018,11.154$ e 11.391, pois o STF ${ }^{55}$ havia ali admitido a possibilidade da realização do auxílio direto em casos de cooperação administrativa envolvendo investigação criminal a pedido das autoridades nos Estados Requerentes, dispensando a necessidade do exequatur. É fato, portanto, que o auxílio direto já era autorizado pelo STF mesmo antes de expressamente previsto na Resolução $n^{\circ} 9$.

Curiosamente, no julgamento do $\mathrm{HC} \mathrm{n}^{\circ} 85.588$ nem se discutiu a questão da eficácia ou não do Tratado de Cooperação Jurídica em Matéria Penal firmado entre a República Federativa do Brasil e a Confederação Suíça ${ }^{56}$, pois os Ministros entenderam que a discussão girava em torno de interpretação de norma constitucional, a qual teria superioridade hierárquica sobre os tratados e convenções, muito embora não se deva interpretar que a Constituição estabeleça alguma vedação à prestação do auxílio direto.

O objetivo da norma constitucional que prevê a necessidade do exequatur é resguardar a soberania do Estado Brasileiro de uma hipotética atuação direta de autoridades judiciárias ou administrativas estrangeiras no território, atuando na mesma linha dos blocking statutes, fazendo valer "a regra geral de que a autoridade estrangeira não pode praticar atos de jurisdição em território nacional ",57. Contudo, o art. 105, I, “i” não estabeleceu a carta rogatória como a única via possível para o atendimento dos requerimentos de autoridades estrangeiras, o que se pode comprovar pela letra do art. 181 da Carta de $1988{ }^{58}$.

\footnotetext{
${ }^{55}$ STF, CR no 10.018, Relatora: Ministra Ellen Gracie, publicada no DJU de 08/02/2002; STF, CR no 11.154 , Relatora: Ministra Ellen Gracie, publicada no DJU de 21/10/2003 STF, CR n ${ }^{\circ} 11.391$, Relatora: Ministra Ellen Gracie, publicada no DJU de 06/12/2004. O primeiro caso versa sobre pedido formulado pela ProcuradoriaGeral de Cuba destinado à identificação completa das pessoas mencionadas no texto rogatório, à remessa de cadastros criminais e de fotos, bem como à obtenção de informações sobre saída do Brasil dessas pessoas, visando esclarecer crime de tráfico de pessoas. Foi determinada a remessa da CR ao Ministério Público Federal para realização das diligências requeridas. O segundo caso trata-se de pedido oriundo do Ministério Público da Colômbia destinado à obtenção de informação sobre uma aeronave, tendo sido decidido que o Ministério Público Brasileiro poderia atender diretamente à solicitação. Finalmente, o terceiro caso cuida de pedido oriundo da Procuradoria da República Popular de Angola destinado à tomada de depoimentos e obtenção de autorização para que oficiais estrangeiros participassem da diligência. Também nessa situação foi determinada a remessa da $\mathrm{CR}$ ao Ministério Público Federal para realização das diligências requeridas.

${ }^{56}$ Firmado em Berna, Suíça em 12/05/2004 e aprovado pelo Decreto Legislativo no 300/2006, mas ainda não promulgado.

57 TIBURCIO, Carmen. Uma breve análise sobre a jurisprudência dos Tribunais superiores em matéria de Direito Internacional no ano de 2006. REVISTA DE DIREITO DO ESTADO, Ano 2, $\mathrm{n}^{\circ}$ 5. Rio de Janeiro: Renovar, p. 79, jan/mar 2007.

${ }^{58}$ Art. 181 - O atendimento de requisição de documento ou informação de natureza comercial, feita por autoridade administrativa ou judiciária estrangeira, a pessoa física ou jurídica residente ou domiciliada no País dependerá de autorização do Poder competente.
} 
Houve novamente confluência entre as decisões do STJ e do STF em matéria de cooperação jurídica internacional em outro caso paradigma, a Carta Rogatória $\mathrm{n}^{\mathrm{o}}$ 570, remetida ao Brasil justamente pela autoridade do Ministério Público da Suíça onde se requeria a realização de uma série de diligências investigativas a respeito de atividades transnacionais de lavagem de dinheiro, inclusive a quebra do sigilo bancário de pessoas aqui domiciliadas. O Ministro Presidente, com base na orientação do STJ a partir da decisão nos Embargos de Declaração no Agravo Regimental na Carta Rogatória $\mathrm{n}^{\circ} 998$ concedeu parcialmente o exequatur afastando a quebra de sigilo bancário pela falta de decisão judicial do país de origem a ser delibada. ${ }^{59}$

Ainda assim um dos interessados impetrou o Habeas Corpus $n^{\circ} 91.002$ perante o STF requerendo a ordem para obstar a realização de todas as diligências solicitadas pelo Ministério Público da Suíça, sob a alegação de que este não teria legitimidade para remeter Carta Rogatória ao país, por não se tratar de uma autoridade judicial como disposto no art. 202, I, CPC.

Após ter concedido liminarmente a ordem requerida, o Relator, Ministro Marco Aurélio assim entendeu no julgamento da causa:

\begin{abstract}
Pois bem, não se trata de rever a legislação do país de origem da carta, nem o ato praticado por autoridade nele existente, mas de perceber se a carta atende, sob o ângulo formal, a legislação brasileira. Consoante dispõe o artigo 202 do Código de Processo Civil, são requisitos essenciais, indispensáveis à valia do ato, quer no tocante à carta precatória e à rogatória a indicação do juízo de origem e de cumprimento do ato. $\mathrm{O}$ ordenamento jurídico brasileiro apenas comporta a cooperação considerados os órgãos dos mesmos níveis, ou seja, órgãos investidos do ofício judicante, não cabendo a magistrado brasileiro cumprir carta rogatória emitida por Ministério Público, pouco importando que este último haja mantido contato com o Ministério Público brasileiro.
\end{abstract}

A Primeira Turma do STF, acompanhando o voto do Ministro Relator, decidiu afastar o cumprimento pelo Judiciário brasileiro da $\mathrm{CR} \mathrm{n}{ }^{\circ} 570 \mathrm{em}$ sua totalidade, ou seja, não apenas a quebra de sigilo bancário como também todas as diligências não poderiam ser realizadas em território nacional, sob o fundamento de que não cabe a magistrado brasileiro cumprir Carta Rogatória emitida por Ministério Público estrangeiro.

Já em sede de Embargos de Declaração oferecidos pelo Ministério Público Federal, este posicionamento foi revisto a fim de corroborar que relativamente à cooperação jurídica internacional com base em tratados ou convenções ratificados e internalizados no

59 "EMBARGOS DE DECLARAÇÃO. CARTA ROGATÓRIA. COOPERAÇÃO INTERNACIONAL. ACOLHIMENTO DOS EMBARGOS PARA FINS DE ACLARAMENTO. SEM EFEITOS MODIFICATIVOS. Para ser exequível no Brasil, a quebra de sigilo bancário deve resultar de decisão judicial emanada de órgão jurisdicional brasileiro ou de sentença estrangeira homologada pelo Brasil.” STJ, CR n 998, Relator: Min. Humberto Gomes de Barros, publicado no DJU de 25/02/2008. 
ordenamento brasileiro, a autoridade estrangeira competente para solicitação das diligências será aquela prevista no ordenamento daquele país, não necessariamente a autoridade judicial. Desse modo, foi denegada a ordem de HC anteriormente concedida, já sendo determinado, por consequiência, pelo Superior Tribunal de Justiça o atendimento do pleito da Carta Rogatória proveniente da Suíça ${ }^{60}$.

Podem-se tecer as mesmas críticas em relação às decisões do STJ e do STF, pois em ambos os casos a lei brasileira foi utilizada como parâmetro exclusivo de formalidade a ser considerado - tanto na forma da exigência de decisão de autoridade judicial para concessão de exequatur às cartas rogatórias requerendo quebra de sigilo bancário, quanto no alegado requisito de conformidade da carta rogatória passiva ao artigo 202, CPC.

A dificuldade em estabelecer qual lei deverá ser aplicada nos procedimentos transnacionais de cooperação jurídica é possível de ser superada através da compreensão dos conceitos de lex fori e lex diligentiae:

\begin{abstract}
There are situations in which the applicability of the lex fori is not certain - for example, acts that must be performed abroad, such as collecting evidence in a foreign jurisdiction, serving a defendant domiciled or residing abroad, or notifying a foreign resident party or nonparty of some act essential to the development of the case. In these situations, should lex fori - the law of the place where the suit was filled - still apply, or should we recognize some exceptions to this rule? When acts are to be performed in another jurisdiction, should we apply local law, either out of respect for another state or as a matter of comity? If so, the lex fori rule would have a different meaning: it would indicate the law of the forum where these specific acts are to be performed. Instead of the actual lex fori, we would have lex diligentiae. ${ }^{61}$
\end{abstract}

Assim, o princípio de respeito à soberania estrangeira impõe que o ato encaminhado pela autoridade de um determinado Estado deva respeitar as formalidades concernentes àquele ordenamento, já no tocante à sua realização, a lei do Estado onde a diligência será efetivamente realizada servirá também como limite a ser observado durante o cumprimento.

Outro fato curioso é que o acórdão faz expressa menção à possibilidade dos acordos e convenções em matéria de cooperação internacional regular as modalidades de cooperação internacional, muito embora o Tratado de Cooperação Jurídica em Matéria Penal firmado entre a República Federativa do Brasil e a Confederação Suíça tenha sido aprovado pelo aprovado pelo Decreto Legislativo $n^{\circ} 300 / 2006$, ainda não foi devidamente publicado. Registre-se novamente, assim, a necessidade de uma maior celeridade das autoridades responsáveis pela efetiva internalização dos tratados celebrados pelo Estado brasileiro, o que

\footnotetext{
${ }^{60}$ STJ, CR n ${ }^{\circ}$ 570, Relator: Ministro Cesar Asfor Rocha, publicada no dia 17/06/2009.

${ }^{61}$ DOLINGER, Jacob ; TIBURCIO, Carmen. The Forum Law Rule in International Litigation : Lex Fori or Lex Diligentiae? - Unresolved Choice-of-Law Issues in the Transnational Rules of Civil Procedure. Texas International Law Journal, vol.33, p.5, 1997.
} 
teoricamente impossibilitaria a produção de efeitos jurídicos dentro do território nacional, de acordo com o sistema de monismo moderado construído pela jurisprudência do STF.

Destarte, as normas do art. 210, CPC; art. 784, CP; art. $7^{\circ}$, parágrafo único da Res. 9; o princípio da reciprocidade e a sólida jurisprudência do próprio STF apontam no sentido da possibilidade da solicitação de cooperação internacional jurídica por autoridades diversas, desde que isto seja atribuição prevista pelo ordenamento jurídico do Estado requerente.

Discussão semelhante também se deu no $\mathrm{HC} \mathrm{n}^{\circ} 87.759^{62}$, impetrado em função da decisão na Carta Rogatória $\mathrm{n}^{\mathbf{0}} \mathbf{7 3 3}$, onde a Primeira Turma concedeu a ordem pleiteada para obstar a realização das diligências solicitadas pelo Ministério Público italiano, muito embora o Ministro Marco Aurélio tenha dado provimento aos embargos declaratórios oferecidos pelo MPF no sentido de reafirmar a possibilidade do Ministério Público Estrangeiro poder enviar carta rogatória ao Brasil. ${ }^{63}$

Há ainda outros precedentes que ilustram essa tendência de confluência nas decisões dos Tribunais Superiores brasileiros em matéria de cooperação internacional tais como $\mathrm{HC}^{\circ}$ $90.485^{64}$, que se originou por força da decisão do Ministro Presidente do STJ na Carta Rogatória $\mathrm{n}^{\mathrm{o}} 1.621$ em que foi concedido o exequatur sem a prévia intimação da parte interessada, conforme o parágrafo único do art. $8^{\circ}$ da Resolução $n^{\circ} 9$.

A maior crítica pode ser feita à decisão em comento é que ela parece estabelecer diferentes níveis no exercício da defesa da soberania nacional, ordem pública e dos bons costumes, como se o prévio juízo de delibação fosse mais adequado para essa tarefa do que a realização do auxílio direto, o que efetivamente não condiz com a realidade, pois essa praxe do sistema concentrado de cooperação judiciária não se revela mais capaz de salvaguardar os valores primordiais do ordenamento, pois o auxílio direto será realizado sob o juízo de admissibilidade tanto da autoridade nacional requerente, quanto o próprio juízo requerido ${ }^{65}$.

Verifica-se, após a decisão no HC 85.588, no âmbito do STJ, uma bipartição na própria jurisprudência em matéria de cooperação internacional; em casos como o da Carta Rogatória $\mathrm{n}^{\mathrm{o}} 1.879^{66}$, o Ministro Presidente deste tribunal baseou-se no acórdão do STF para

\footnotetext{
${ }^{62}$ STF, HC no 87.759, Relator: Min. Marco Aurélio, publicado no DJU de 17/04/2008.

${ }^{63}$ Pediu vista a Ministra Carmen Lúcia em 17/03/2009.

${ }^{64}$ STF, HC no 90.485, Relator: Ministro Cesar Peluso, publicado no DJU de 08/06/2007.

${ }^{65}$ MILLER, Marcello Paranhos de Oliveira. $O$ auxílio direto em matéria penal: a moldura jurídica de uma nova vertente da cooperação internacional. Dissertação de Mestrado em Direito Internacional e Integração Econômica pela Universidade do Estado do Rio de Janeiro. Orientadora: Professora Carmen Tiburcio. Rio de Janeiro: UERJ, 2008, p.175-178.

66 “Ante o disposto no art. 105, I, “i”, da Lei Maior, a Suprema Corte considerou, no referido precedente, que a única via admissível para a solicitação de diligência proveniente do exterior é a carta rogatória, a qual deve submeter-se previamente ao crivo do Superior Tribunal de Justiça. Assim, a despeito do disposto no art. $7^{\circ}$,
} 
dizer que quaisquer medidas de cooperação jurídica internacional deveriam ser remetidas ao país por via rogatória, atente-se ainda para o fato de que no caso ambos os países eram ratificantes da Convenção de Palermo e, ainda assim, parte dos pedidos foi recusada por alegada contrariedade ao artigo 105, I, “ $i$ ”da Constituição Federal.

Por outro lado, dê-se destaque para a decisão na Carta Rogatória n ${ }^{\circ} 3.248$, decidindo em sentido diametralmente oposto, entendendo que a ausência da necessidade do juízo de delibação permite a conversão das diligências requeridas, conforme consta do parágrafo único do artigo $7^{\circ}$ da Resolução $n^{\circ}$ 9, no mesmo sentido veja-se a decisão na Carta Rogatória $n^{\circ}$ $1.969^{67}$ :

1. Cuida-se de carta rogatória em que a Justiça do Principado de Mônaco pede a localização e o interrogatório de Patrícia da Costa Franco que seria, na verdade, Alzira Rodrigues Soares ou Alzira Soares e Silva, a qual responde a processo por delitos de fraude e estelionato. 2. O Ministério Público Federal considera tratar-se no caso de cooperação administrativa, na linha de precedentes oriundos da Suprema Corte que relaciona (fl. 28). 3. Posto isso, determino seja encaminhada esta carta rogatória ao Ministério Público Federal, a fim de que ele realize diretamente as diligências pertinentes.

Essa divergência na jurisprudência recente do STJ em matéria de cooperação internacional torna-se patente no caso da Reclamação $\mathrm{n}^{\circ} 2.645$, em que se discute questão semelhante àquela verificada na Reclamação $\mathrm{n}^{\mathrm{o}}$ 1.819. Trata-se uma possível usurpação de competência do STJ, consubstanciado na decisão de o Juiz da $6^{\mathrm{a}}$ Vara Criminal da Subseção Judiciária de São Paulo de autorizar, a pedido do MP Federal, a remessa de cópia do "hard disk" apreendido no Brasil, requerido pela Procuradoria Geral da Federação Russa.

O Ministro Relator concedeu liminarmente a suspensão do ato com base na jurisprudência do STF, entretanto, já no julgamento pela Corte Especial, o Ministro Zavascki sustentou que o sistema de cooperação entre os Estados soberanos vai muito além das relações decorrentes de atos de natureza jurisdicional, havendo uma gama de medidas no direito interno que, embora possam dar ensejo a futuras ações penais, não exigem prévia aprovação ou intermediação judicial para sua execução, motivo pelo qual não há razão para impedir a realização do auxílio direto solicitado, o julgamento parcial na Corte Especial apontava que o voto do Relator pela improcedência da Reclamação contava com o apoio de treze outros ministros, contra sete no sentido da procedência, já tendo havido três pedidos de vista $^{68}$.

parágrafo único, da Resolução n. 9, da Presidência do STJ, de 4.5.2005, a qual - à evidência - não pode prevalecer diante do texto constitucional, a execução das diligências solicitadas deve ocorrer via carta rogatória. Acresce que, no caso, há necessidade de juízo de delibação, a ser exercido por esta Corte Superior, não só em razão dos pedidos executórios e de oitiva de pessoas, mas porque se objetiva a presença de Magistrado estrangeiro, do Substituto-Procurador do Rei, do escrivão, de inspetores e de tradutores na execução das diligências." STJ, CR n ${ }^{\circ}$ 1.879, Relator: Ministro Barros Monteiro, publicada no DJU de 04/05/2007.

${ }^{67}$ STJ, CR no 1.969, Relator: Ministro Barros Monteiro, publicada no DJU de 01/02/2007.

${ }^{68}$ Último acompanhamento em 11/05/2010. 
Denota-se, dessa forma, uma crescente influência das decisões do STF sobre os julgados do STJ em matéria de cooperação jurídica internacional, especialmente em diligências investigativas.

Através da utilização repetitiva do instrumento do Habeas Corpus, corre-se o risco de transformar a Suprema Corte Brasileira em nicho para impetração de recursos que acabam por estabelecer uma nova espécie de controle sobre a realização da cooperação jurídica internacional; é preciso que os Ministros de ambas as casas atuem no sentido de preservar a independência funcional e valorativa de cada Tribunal, especialmente porque a reforma constitucional deslocou para o STJ a competência para analisar a necessidade e o cabimento do exequatur aos requerimentos enviados ao Estado brasileiro, além do fato de que a via do auxílio direto já teve seu cabimento diversas vezes reconhecido no ordenamento pátrio.

\section{Conclusões}

Os sujeitos do Direito Internacional Contemporâneo buscam se articular em torno da cooperação jurídica internacional seja criando fontes formais eficazes no combate às ameaças, tais como as Convenções da ONU sobre Combate ao Crime Organizado Transnacional, como também promovendo áreas de integração econômica ou ainda realizando tratados bilaterais no sentido da facilitação da cooperação e da correlata prestação jurisdicional efetiva e eficaz.

A EC no 45/04 bipartiu entre o STF e o STJ a competência para o juízo de admissibilidade em matéria de cooperação jurídica internacional, sendo que a homologação de sentenças estrangeiras e a concessão de exequatur às cartas rogatórias passaram a ser processadas perante o Superior Tribunal de Justiça, cuja Resolução n 9/05 se tornou a regra geral a ser aplicada na ausência de tratado ou convenção de cooperação jurídica internacional.

Entretanto, a análise da jurisprudência recente destas duas cortes revela que está havendo grande confluência entre as decisões do STF e do STJ em matéria de cooperação internacional, com divergências bastante amplas no tocante à possibilidade da realização do auxílio direto, dispensando a via da carta rogatória e da legitimidade para o requerimento das diligências ao Estado Brasileiro.

Tendo em vista o uso repetido da impetração de Habeas Corpus, o que se percebe nitidamente é a crescente influência das decisões da Suprema Corte no entendimento do Superior Tribunal de Justiça em matéria de cooperação jurídica internacional, o que acaba por esvaziar as reformas pretendidas pela própria EC 45/04, na medida em que se tentava desafogar o STF do número excessivo de casos a julgar, resguardando seu perfil de guardião da Constituição.

Ademais, se houve uma reconfiguração do sistema de cooperação internacional jurídica no sentido de conferir ao STJ a competência para o juízo de delibação das cartas rogatórias, sentenças estrangeiras e da concessão do auxílio direto, não faz sentido que a 
matéria continue chegando ao STF através do Habeas Corpus, especialmente porque praticamente todas as medidas em matéria de cooperação internacional poderão em tese ser apreciadas no julgamento do remédio heróico.

Torna-se necessário, portanto, que haja uma consolidação na jurisprudência dos Tribunais brasileiros no sentido da conscientização da cooperação internacional para assim possibilitar que tanto o STJ quanto o STF possam atuar de maneira harmoniosa, onde cada órgão exercerá suas atribuições de maneira a contribuir para a prestação jurisdicional dinâmica, justa, eficaz e transparente, seja num caso interno ou em atenção ao processo demandado em território alienígena, pois conforme já ensinava Phillip Jessup ${ }^{69}$, um Direito Internacional verdadeiramente coerente com as circunstâncias dessa novíssima ordem mundial entenderia a jurisdição não somente como um atributo irredutível da soberania, mas primordialmente como aspiração máxima à realização da dignidade da pessoa humana e da justiça.

\section{BIBLIOGRAFIA}

ALMEIDA, Bruno Rodrigues de. Cooperação Jurídica Internacional em perspectiva: análise da jurisprudência dos Tribunais Superiores brasileiros sobre a denegação do exequatur às cartas rogatórias passivas por ofensa à ordem pública, soberania nacional e os bons costumes. Dissertação de Mestrado em Direito Internacional e Integração Econômica pela Universidade do Estado do Rio de Janeiro. Orientadora: Professora Carmen Tiburcio. Rio de Janeiro: UERJ, 2008.

ARAUJO, Nadia de. Direito Internacional Privado - Teoria e Prática Brasileira. $4^{\mathrm{a}}$ edição. Rio de Janeiro: Renovar, 2008

; MARQUES, Cláudia Lima (organizadoras). O novo Direito Internacional - estudos em homenagem a Erik Jayme.

BARBOSA MOREIRA, José Carlos. Temas de Direito Processual - Quinta Série. São Paulo: Saraiva, 1994.

BARROSO, Luís Roberto; TIBURCIO, Carmen (org.). O Direito Internacional Contemporâneo - Estudos em homenagem ao Professor Jacob Dolinger. Rio de Janeiro: Renovar, 2006.

BASSO Maristela (org.) Mercosul, seus efeitos jurídicos, econômicos e políticos nos Estados Membros. Porto Alegre: Livraria do Advogado, 1997.

BRANT, Leonardo Nemer Caldeira (Coord.). O Brasil e os novos desafios do Direito Internacional. Rio de Janeiro: Forense, 2004.

CASELLA, Paulo Borba e SANCHEZ, Rodrigo Elian. (organizadores). Cooperação Judiciária Internacional. Rio de Janeiro: Renovar, 2002.

CASTELLS, Manuel de. A Era da Informação: Economia, Sociedade e Cultura, Volume III Fim de Milênio. Rio Janeiro: Paz e Terra, 1999.

\footnotetext{
69 JESSUP, Philip. Direito Transnacional. Trad. Carlos Ramires Pinheiro da Silva. Rio de Janeiro: Fundo de Cultura, 1965, p. 62.
} 
COCKAYNE, James. Transnational Organized Crime: multilateral responses to a rising threat. 2007.Disponível em http://www.ipacademy.org/asset/file/159/CWC_Working paper_ORGANIZED_CRIME_JC.pdf

COCKAYNE, John; MIKULASCHEK, Cristoph. Transnational Security Challenges and the United Nations: Overcoming Sovereignty Walls and Institutional Silos, 2008. Disponível em <<http://www.ipacademy.org/asset/file/253/westpoint.pdf. >>

DINIZ, Maria Helena. Lei de Introdução ao Código Civil Brasileiro Interpretada. 14a edição. São Paulo: Saraiva, 2009.

DIREITO, Carlos Alberto Menezes; PEREIRA, Antonio Celso Alves; TRINDADE, Antonio Augusto Cançado (Organizadores). Novas perspectivas do direito internacional contemporâneo - Estudos em homenagem ao Professor Celso D. de Albuquerque Mello. Rio de Janeiro: Renovar, 2008.

DOLINGER, Jacob. Direito Internacional Privado - Parte Geral. $9^{\text {a }}$ edição. Rio de Janeiro: Renovar, 2008.

Direito Internacional Privado (Parte Especial) - Direito Civil Internacional Volume II - Contratos e obrigações no Direito internacional privado. Rio de Janeiro: Renovar, 2007.

JESSUP, Philip. Direito Transnacional. Trad. Carlos Ramires Pinheiro da Silva. Rio de Janeiro: Fundo de Cultura, 1965.

LEWANDOWSKI, Enrique Ricardo. Globalização e soberania. In: CASELLA Paulo Borba et al (org.) Direito internacional, humanismo e globalidade, São Paulo: Atlas, 2008.

LOWENFELD, Andreas F. Public Law in the International Arena: Conflict of Laws, International Law, and some suggestions for their interaction. Haia: Alphen Van Den Rijn Sitjtholf M. Noodhroff Editores, 1980.

MANCINI, Pasquale Stanislao. Direito Internacional. Ijuí: Unijuí, 2003.

MELLO, Celso D. de Albuquerque. Curso de Direito Internacional Público. $1^{\circ}$ Volume. $11^{\mathrm{a}}$ edição. Rio de Janeiro: Renovar, 1997.

MELLO. Celso D. de Alburquerque (coordenador). Anuário: Direito e Globalização, Volume I Soberania. Rio de Janeiro: Renovar, 1999.

MILLER, Marcello Paranhos de Oliveira. $O$ auxílio direto em matéria penal: a moldura jurídica de uma nova vertente da cooperação internacional. Dissertação de Mestrado em Direito Internacional e Integração Econômica pela Universidade do Estado do Rio de Janeiro. Orientadora: Professora Carmen Tiburcio. Rio de Janeiro: UERJ, 2008.

NAÍM, Moisés. The Five Wars of Globalization. Versão eletrônica disponível em <<http://www.ipacademy.org/asset/file/279/5wars.pdf>>

NGUYEN, Q. D., DAILliER, P., \& PELLET, Allain. Direito Internacional Público. $2^{\mathrm{a}}$ edição. Lisboa: Fundação Calouste Gulbenkian, 2003.

ÖRÜCÜ, Esin; NELKEN, David, ed. Comparative Law: a handbook. Portland: Oregon, 2007. PEREIRA, Luís Cezar Ramos. Costume Internacional - Gênese do Direito Internacional. Rio de Janeiro: Renovar, 2002.

QUINTANA, Lucio Moreno. Tratado de Derecho Internacional. Volume I. Buenos Aires: Editorial Sudamericana, 1963.

RIBEIRO, Marilda Rosado de Sá. Cooperação Internacional. No prelo.

SAHOVIC, Milan. Principles of International Law concerning Friendly Relations and Cooperation. Belgrado: Delo, 1972.

SAVIGNY. Friedrich Carl Von. Sistema de Direito Romano Atual, volume VII. Trad. Ciro Mioranza Ijuí: Unijuí, 2004.

STORY, Joseph. Comentarios sobre el Conflicto de Las Leyes. Claudomiro Quiroga (Trad.). Buenos Aires: Felix Lajouane, 1891.

TIBURCIO, Carmen. Temas de Direito Internacional. Rio de Janeiro: Renovar, 2006. 
VAN DUYNE, P.C. The Phantom and Threat of Organized Crime .In: Crime, Law and Social Change, vol. 24. Nova York: Springer, 1995.

WILLIAMS, Phill. Strategy for a New World : Combating Terrorrism and Transnational Organized Crime. Disponível em <<http://www.ipacademy.org/asset/file/278/stratphil.pdf. $>>$ 